\title{
Relevansi Pembuatan Keputusan \\ Dalam Organisasi Pendidikan Islam
}

\section{RELEVANSI PEMBUATAN KEPUTUSAN \\ DALAM ORGANISASI PENDIDIKAN ISLAM}

\author{
Didin Sirojudin, M.Pd.I \\ Dosen Universitas KH. A. Wahab Hasbullah \\ Mr.didinsirojudin@gmail.com
}

\begin{abstract}
Organization and leadership related to decision making. So leaders have authority in decision making. In reality if in the leadership of Islamic educational institutions, there is still a madrasa head running his leadership with all-mono policies, namely monomanagement, monokepemership, monocepecial, and so forth, then this situation will cause the impression of being less organized and authoritarian. The organization will only function if the leaders have the ability to make decisions, and instruct its implementation to members of the organization in accordance with their area of duties and responsibilities. Decisions in Islamic educational institutions are steps to solve the problems that exist when designing an education to achieve goals.
\end{abstract}

Keyword : Stakeholder, Organizations, Islamic Education Institutions.

\section{A. Pendahuluan}

Sebuah organisasi merupakan wadah bagi beroperasinya manajemen. Di sini aktivitas manajemen menjadi salah satu subsistem dari organisasi.Manajemen menjadi teknik atau alat yang menggerakkan organisasi menuju tercapainya tujuan yang diinginkan.Dalam konteks tugas manajer, pembuatan keputusan merupakan salah satu peranan manajer yang disebut peranan desisional. ${ }^{1}$

Kepemimpinan berkaitan dengan pembuatan keputusan.Jadi pemimpin memiliki wewenang dalam pembuatan keputusan. Pada realitasnya bila dalam kepemimpinan lembaga pendidikan Islam, masih ada kepala madrasah menjalankan kepemimpinannya dengan kebijakan serba mono, yaitu monomanajemen, monokepemimpinan, monokeputusan, dan lain sebagainya, maka keadaan ini akan menimbulkan kesan kurang teratur dan otoriter. Bila figur kepala lembaga pendidikan Islam tidak profesional, maka akan berdampak kurang baik bagi lembaga pendidikan dan bahkan akan mendatangkan berbagai kerugian, seperti, kesan kepemimpinan yang tidak sehat bahkan bisa mengakibatkan kemerosotan kualitas, penurunan prestasi, respon negatif dari masyarakat, konflik, dan berbagai fenomena

\footnotetext{
${ }^{1}$ Syafaruddin, Manajemen Lembaga Pendidikan Islam, (Jakarta: Ciputat Press, 2005), h. 44.
} 


\section{Didin Sirojudin.}

kontraproduktif. Oleh karena itu idealnya, pimpinan lembaga pendidikan Islam hams lebih professional, serta akomodatif terhadap semua pihak yang terkait sehingga kepemimpinannya mencerminkan kepemimpinan demokratis-partisipatif.

Pembuatan keputusan berhubungan dengan masalah yang dihadapi dalam suatu organisasi. Sutjahjanti menyatakan bahwa pembuatan keputusan merupakan pendekatan sistematis terhadap suatu masalah dengan cara pengumpulan fakta dan data atau informasi yang relevan dengan masalah tersebut sehingga dapat ditentukan alternatif yang menurut perhitungan merupakan tindakan yang tepat. ${ }^{2}$ Dengan demikian dapat dipahami bahwa dalam pembuatan keputusan diperlukan informasi yang berkualitas yang dapat menentukan alternatif tindakan yang akan dilakukan.

\section{B. Pengertian Pembuatan Keputusan}

Menurut bahasa Keputusan berasal dari kata putus: habis.rampung.selesai.berakhir.mendapat imbuhan ke - an menjadi keputusan: berkesudahan; berakhir; ada keputusan (akhirnya): tidak . tidak ada kesudahannya (akhirnya. putusputusnya). ${ }^{3}$ Secara istilah keputusan adalah pengakhiran daripada proses pemikiran tentang apa yang dianggap sebagai "masalah" sebagai sesuatu yang merupakan penyimpangan daripada yang dikehendaki.direncanakan atau dituju dengan menjatuhkan pilihan pada salah satu alternatif pemecahannya (Atmosudirdjo. 1990: 45). ${ }^{4}$

Dari pengertian diatas dapat disimpulkan bahwa keputusan haruslah relevan dengan sebuah tujuan dan perencanaan suatu masaalah.sebuah keputusan dapat berarti hasil rumusan pemikiran yang didasarkaan pada visi dan misi sebuah lembaga untuk mengatur jalannya pekerjaan demimencapai tujuan bersama.
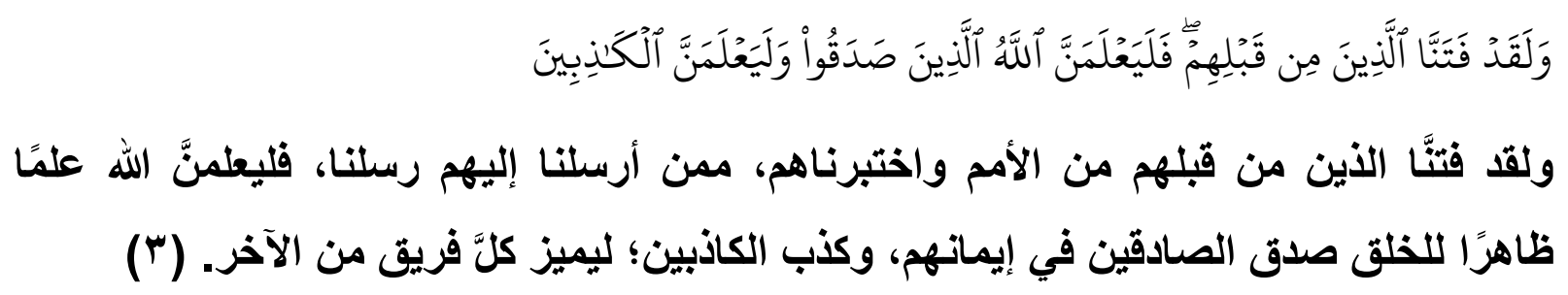

\footnotetext{
${ }^{2}$ Ambar Sutjahjanti, "Kualitas dan Nilai Infonnasi sebagai Proses Pembuatan keputusan dan Pengendalian Manajemen," dalam Jurnal E,konomi dan Man4emen,vol. VI, h. 396.

${ }^{3} \mathrm{KBBI}$ offline, 2010- 2013 diambil dari http://pustakabahasa.kemdiknas.go.id/kbbi

${ }^{4}$ Sabri, 2013,Kebijakan dan Pengambilan Keputusan dalam Pendidikan Islam, Jurnal Al-Ta'lim Jilid 1 Nomor 5, hlm. 373-379
} 


\section{Relevansi Pembuatan Keputusan \\ Dalam Organisasi Pendidikan Islam}

dan Sesungguhnya Kami telah menguji orang-orang yang sebelum mereka. Maka Sesungguhnya Allah mengetahui orang-orang yang benar dan Sesungguhnya Dia mengetahui orang-orang yang dusta. (QS Al Ankabut; ayat 3$)^{5}$

Ayat diatas mengajarkan hendaknya ketika membuat sebuah keputusan akan lebihbaik jika kita mengevaluasi hal - hal yang bersangkutan dengan dunia pendidikan Islam agar jika ada suatu massalah yang menjadikanterhalangnya tujuan pendidikan itu mampu diperbaiki.dengan tahu mana yang harus ditingkatkan dan mana yang harus diperbaiki.bukan justru hal - hal yang menjadikan terhalangnya tujuan itu di hapus dan diganti dengan tujuan lain. karena jika demikian akan memakan waktu dan bisa jadi tujuan yang lain kurang maksimal hasilnya.

Keputusan merupakan langkah memecahkan msalah yang terdapat disaat merancang sebuah pendidikan.setelah mengevaluasi hal - hal yang bersangkutan dalam pendidikan maka permasalahan ini dapatdi pecahkan dengan beberapa metode.salah satunya analisis $\mathrm{SWOT}^{6}$.

\section{Pembuatan kepuptusan dalam Pendidikan islam}

Organisasi hanya akan berfungsi jika pars pemimpin memiliki kemampuan Pembuatan keputusan, dan memerintahkan pelaksanaannya kepada pars anggota organisasi sesuai dengan bidang tugas dan tanggung jawabnya. Keputusan pada dasarnya berarti hasil akhir dalam mempertimbangkan sesuatu, yang akan dilaksanakan secara nyata. Keputusan dapat diartikan juga hasil terbaik dalam memilih satu di antara dua atau beberapa alternatif yang dihadapi. $^{7}$

Selain sebagai kumpulan orang, organisasi adalah sistem pengambilan keputusan dan pengolahan informasi.Organisasi membantu pencapaian tujuan melalui koordinasi dari usaha

\footnotetext{
${ }^{5}$ Mohammad Taufiq, Al Qur'an In Word,

${ }^{6}$ Fajar Sulistiyo, 2008, Analisis SWOT, didalam websitelib.ui.ac.id/file?file=digital/130215-T\%2024763Manajemen\%20sistem-Literatur.pdf (diakses tanggal 4 januari 2015)

${ }^{7}$ Hadari Nawawi, Kepemimpinan Menurut Islam (Yogyakarta: Gadjah Mada University
} Press, 1993), h. 55. 


\section{Didin Sirojudin.}

kelompok. pengambilan keputusan dan pengolahan informasi adalah hal utama agar koordinasi dapat terlaksana. ${ }^{8}$

Para manajer - dimanapun mereka tempatnya dalam organisasi - membuat keputusan.Seorang manajer biasanya harus membuat pilihan mengenai tujuan, alokasi anggaran, personalia, cam melaksanakan pekerjaan, dan cam memperbaiki keefektifan unitnya. ${ }^{9}$

Syafaruddin mengemukakan bahwa pengambilan keputusan adalah proses pemecahan masalah dengan menentukan pilihan dari beberapa alternatif untuk menetapkan suatu tindakan dalam mencapai tujuan yang diinginkan. Deftnisi ini mengandung dua substansi pokok yaitu: ada kebutuhan memecahkan masalah, adanya proses (langkahlangkah), ada beberapa alternatif yang akan dipilih (bukan satu alternatif), ada ketetapan hati memilih satu pilihan, dan ada tujuan pembuatan keputusan (disengaja). ${ }^{10}$

Menurut Usman, pengambilan keputusan adalah proses memilih sejumlah alternatif. Sikap memilih sebuah alternatif bukanlah hal yang mudah.Pembuatan keputusan penting bagi administrator pendidikan karena proses pembuatan keputusan mempunyai peran penting dalam motivasi, kepemimpinan, komunikasi, koordinasi, dan perubahan organisasi. $^{11}$

Menurut Qomar, pengambilan keputusan merupakan langkah penting dalam organisasi. Hal ini dikatakan penting karena keputusan itulah yang menghasilkan programprogram yang akan dilaksanakan dalam organisasi. Bila ada organisasi tanpa keputusan, berarti organisasi itu tidak memiliki program kerja yang hams dilaksanakan, berarti juga organisasi tersebut mati secara substansi, tidak bergerak sama sekali. ${ }^{12}$

Robbins mengemukakan bahwa pengambilan keputusan merupakan usaha membuat pilihan-pilihan.Setelah mengembangkan dan mengevaluasi paling sedikitnya dua alternatif, pengambil keputusan memilih alternatif yang disukai.Dilihat dari pandangan seorang

\footnotetext{
${ }^{8}$ Stephen P. Robbins, Teori Organisasi: Struktur, Desain \& Aplikasi. Terj. Jusuf Udaya, (Jakarta: Arcan, 1994), h. 120 ${ }^{9}$ Ibid

${ }^{10}$ Syafaruddin.Manajemen Lembaga Pendidikan Islam, h. 48.

${ }^{11}$ Husaini Usman, Manajemen Teori, Praktik, dan Riset Pendidikan, (Jakarta: Bumi Aksara, 2006), h. 321.

${ }^{12}$ Mujamil Qomar, Manajemen Pendidikan Islam, (Jakarta: Erlangga, 2007), h. 292.
} 


\section{Relevansi Pembuatan Keputusan Dalam Organisasi Pendidikan Islam}

pengambil keputusan ini merupakan penyampaian yang cukup memuaskan. Tetapi jika dilihat dari pandangan organisasi, pembuatan pilihan hanya merupakan salah satu langkah dari proses yang lebih luas. ${ }^{13}$

Dari berbagai pendapat ahli di atas, penulis menyimpulkan bahwa pengambilan keputusan merupakan tindakan yang diperlukan berkaitan dengan sesuatu hal yang direncanakan atau terprogram maupun yang tidak terprogram sesuai kebutuhan dan berdasarkan pertimbangan pimpinan, dan anggota bila diperlukan, atau sesuai dengan mekanisme pembuatan keputusan yang berlaku dalam organisasi atau lembaga.

\section{Sistem Pembuatan Keputusan}

Sistem adalah satu rangkaian dari unsur-unsur yang sating terkait, disatukan oleh desain untuk mencapai beberapa tujuan atau sasaran. ${ }^{14}$ pengambilan keputusan merupakan suatu sistem tindakan karena itu ada beberapa komponen di dalamnya. Menurut Atmosudirjo sebagaimana dikutip oleh Syafaruddin menjelaskan kerangka kerja yang ada dalam sistem pengambilan keputusan yaitu:

a. Posisi orang yang berwenang dalam mengambil keputusan;

b. Problema (penyimpangan dari apa yang dikehendaki dan direncanakan atau dituju);

c. Situasi pengambil keputusan itu berada;

d. Kondisi pengambil keputusan (kekuatan dan kemampuan menghadapi problem); dan

e. Tujuan (apa yang diinginkan atau dicapai dengan pembuatan keputusan). ${ }^{15}$

Setiap level (tingkat) manajemen berperan dalam proses pembuatan keputusan, namun keputusan yang diambil sesuai dengan kewenangan yang diberikan kepada setiap manajer. Bagi manajemen puncak (top management), tingkat keputusan yang diambilnya terdiri dari menyusun strategi, kebijakan dan peraturan unium yang proporsinya berimbang dalam perencanaan, operasional, dan pengawasan.Misi dan visi serta sasaran organisasi disusun oleh manajemen puncak yang biasanya dipercayakan oleh pemilik organisasi atau perusahaan. $^{16}$

\footnotetext{
${ }^{13}$ Robbins, Teori Organisasi, h. 120

${ }^{14}$ Syafaruddin, Efektivitas Kebijakan, h. 44

${ }^{15}$ Syafaruddin, Manajemen Lembaga, h. 48.

${ }^{16} \mathrm{Ibid}$, h. 59.
} 


\section{Didin Sirojudin.}

Pemimpin dalam bidang apa saja harulos mampu menghasilkan keputusankeputusan fungsional. Artinya, keputusan yang benar-benar mengikat seluruh anggota suatu organisasi untuk mematuhi dan menjalankannya bersama-sama, baik dengan keterpaksaan maupun dengan kesadaran. Keterpaksaan bagi orang tertentu mungkin terjadi meskipun sedapat mungkin dihindarkan, karena seseorang hams menyesuaikan diri dengan keputusankeputusan yang telahditetapkan dan diberlakukan bagi semua jajaran organisasi, mulai dari pimpinan sampai staf paling bawah. ${ }^{17}$

Keputusan-keputusan tersebut berhubungan sangat erat dengan kepemimpinan. Suatu kepemimpinan tanpa melahirkan keputusan, ibarat raga tanpa ruh, tidak ada artinya sama sekali. Jika inti manajemen ada pada kepemimpinan, Siagian menegaskan bahwa inti kepemimpinan adalah pembuatan keputusan. Pemimpin hams berani mengambil keputusan meskipun ternyata di kemudian hari keputusan itu Baru diketahui salah. Keputusan yang salah sekalipun dapat dianulir dan diganti dengan keputusan yang benar, keputusan yang menyebabkan perilaku yang positif ${ }^{18}$

Pembuatan keputusan merupakan bagian dari standar daya saing global. ${ }^{19}$ Pembuatan keputusan berpotensi melahirkan perubahan iklim pada suatu organisasi. Mengingat begitu pentingnya peran pembuatan keputusan, tidak jarang di beberapa sekolah menuntut keterlibatan aktif (partisipasi) pendidik dan tenaga kependidikan dalam mendukung proses pendidikan di suatu lembaga pendidikan.

Syafaruddin berpendapat bahwa partisipasi merupakan syarat yang esensial jika guru dan staf diharapkan akan dapat merasa bahwa mereka menjadi bagian perubahan dan tidak hanya sebagai pelaksana perubahan yang dikembangkan oleh orang lain. Partisipasi akan menjamin bahwa orang-orang memiliki komitmen murni untuk memuneullcan rencana dan melaksanakannya.Keterlibatan para pendidik dari semua strata dan organisasi adalah sangat penting ketika perubahan dipikirkan. Di sini perencanaan partisipatif dan pengembangannya adalah penting. ${ }^{20}$

\footnotetext{
${ }^{17}$ Qomar, Manajemen, h. 291,

${ }^{18}$ Sondang P. Siagian, Fungsi-Fungsi Manajerial (Jakarta: Bina Aksara, 1989), h. 8.

${ }^{19}$ Syafaruddin, Efektivitas Kebijakan, h. 28.

${ }^{20}$ Ibid, hal. 42
} 


\section{Relevansi Pembuatan Keputusan Dalam Organisasi Pendidikan Islam}

Dari kutipan-kutipan di atas, penulis menyimpulkan bahwa pembuatan keputusan berhubungan dengan kepemimpinan.Seorang pemimpin yang efektif adalah pemimpin yang mampu menggerakkan bawahan untuk berpartisipasi dalam pembuatan keputusan (keputusan partisipatif).

\section{E. Langkah-Langkah Pembuatan Keputusan}

Setiap manajer perlu memahami langkah-langkah pembuatan keputusan sebagaimana dikemukakan oleh Mondy dan Premeaux yang terdiri dari lima langkah yaitu:

a. Mengidentifikasi masalah atau peluang

Langkah ini dimaksudkan untuk mempelajari atau mengenali masalah yang dihadapi atau peluang apa sajakah yang hams ditangkap oleh organisasi dalam meningkatkan perannya di masa depan. Pada langkah ini diperlukan perumusan masalah sebagai bagian penting dalamproses pembuatan keputusan, karena hal ini menentukan tindakan yang akan diambil.

b. Membuat alternatif-alternatif

Membuat altematif yang diperkirakan akan dapat menjadi jawaban dalam pemecahan masalah adalah sangat penting. Sebab sebagai altematif yang dibuat akan dapat dipilih altematif yang paling menguntungkan dalam memecahkan masalah yang dihadapi.

c. Mengevaluasi alternatif

Menilai keuntungan dan kerugian atau kekuatan dan kelemahan dari masing-masing alternatif di dalam memecahkan masalah dan menjawab peluang yang ada merupakan langkah yang akan menentukan pilihan.

d. Memiliki dan Mengimplementasikan Alternatif

Adapun tindakan memilih altematif terbaik dari sejumlah alternatif yang diajukan dalam mendukung keberhasilan pemecahan masalah dan menjawab peluang yang ada dalam organisasi merupakan langkah keempat.Pemilihan altematif itu sekaligus menetapkannya untuk dilaksanakan sebagai keputusan yang diambil bagi organisasi.

e. Mengevaluasi Alternatif 


\section{Didin Sirojudin.}

Keputusan yang telah dilaksanakan haruslah dievaluasi apakah telah mencapai tujuan yang diinginkan atau belum. Sebab keputusan itu diyakini sebagai cara dalam memecahkan masalah atau mengisi peluang untuk menjawab kebutuhan organisasi. ${ }^{21}$

Sebagai perbandingan tentang tahapan pembuatan keputusan seperti tersebut diatas, berikut dikemukakan tahap-tahap pembuatan keputusan dari ahli yang lain. Gibson, et.al.mengemukakan bahwa kemampuan mengelola keputusan merupakan ujung tombak dan sekaligus ukuran keefektifan seorang manajer. Dia mengklasifikasi tahapan pembuatan keputusan meliputi:

1. Memunculkan tujuan umum dan khusus untuk mengukur hasil organisasi.

2. Mengidentifikasi masalah yang menghambat terwujudnya tujuan organisasi.

3. Mengembangkan berbagai altematif untuk pemecahan masalah.

4. Mengevaluasi altematif dan memilih satu altematif yang dianggap paling optimal mewujudkan tujuan organisasi

5. Mengukur dan mengevaluasi keputusan secara periodik. ${ }^{22}$

Pembuatan keputusan yang tidak efektif banyak penyebabnya, mulai dari kerumitan lingkungan usaha sampai gaya manajemen dan falsafah yang saling bertentangan. Tapi, salah satu penyebab yang paling umum adalah ketidakmampuan organisasi dalam mendesain proses keputusan, mengidentifikasi keputusan rinci, menentukan bagaimana mereka dibuat, dan mengusahakan agarproses tersebut tidak bertentangan dengan struktur organisasional dan mekanismemekanisme pendukung. ${ }^{23}$

Sulit untuk menemukan organisasi yang keputusannya tidak melampau tapal-batas organisasional, yang pembuatan keputusannya tidak melibatkan kelompok-kelompok dengan tujuan berbeda, yang tanggung jawab kelompok atau individu, staf dan lini-nya tidak pemah bertentangan.Di titik-titik temu inilah kemacetan cenderung terjadi.Organisasi cenderung berhenti, tidak pada substansi masalah tapi pada bagaimana sebuah keputusan diambil.Apabila organasasi mengejar implementabilitas, organisasi harus melakukan hal-hal berikut ini.

\footnotetext{
${ }^{21}$ Syafaruddin, Manajemen Lembaga, h. 54.

${ }^{22}$ James L. Gibson, eral.Organkations. Behavior, Structure, Process (New York: McGraw Hill, 2003), ed. XI, h. 440.

${ }^{23}$ Frances Hesselbein, etal.(Eds.), Organisasi Masa Depan. Ted. Achmad Kemal, cet. 2 (Jakarta: Elex Media Komputindo, 2001), h. 73.
} 


\section{Relevansi Pembuatan Keputusan Dalam Organisasi Pendidikan Islam}

a. Menentukan keputusan-keputusan kunci yang dibutuhkan untuk menerapkan suatu strategi.

b. Mengidentifikasi masalah-masalah penting, data, dan analisis yang dibutuhkan.

c. Memerinci peranan dan tanggung jawab setiap individu dan kelompok yang terlibat.

d. Menjelaskan tentang proses dan waktu manakala orang dan informasi yang dibutuhkan akan bertemu. $^{24}$

Ada dua alat yang dapat digunakan dalam pembuatan keputusan, yaitu suatu form proses pemetaan untuk keputusan-keputusan kunci. Cara ini memperlihatkan secara visual catatan kronologis dari para pemain yang mengambil keputusan dan jalur yang sering kali menghambat, yang dijadikan dasar keputusan organisasi. Memetakan keputusan-keputusan masa lalu penting untuk menggali lagi ketidakefektifannya dan untuk mengevaluasi keefisiensian proses pembuatan keputusan yang berlaku sekarang. Cara ini juga dapat menjadi data bagi eksekutif untuk memperbaiki persepsi mereka mengenai apa yang seharusnya dilakukan. Alat kedua adalah matriks yang akan membantu mendesain proses pembuatan keputusan yang barn. Matriks ini mengidentifikasi keputusan-keputusan kunci organisasi pada salah satu sumbu matriks, dan pelaku-pelaku untuk setiap keputusan pada sumbu yang satu lagi, dan menggambarkan peranan rekomendasi, persetujuan, input, atau memutuskan (recommend, agree, input, or decide - RAID) - di mana setiap individu atau kelompok akan berperan dalam setiap keputusan. ${ }^{25}$

Apabila pelaku pengambil keputusan memulai dengan melakukan analisis keputusan terlebuh dahulu, pengambil keputusan akan segera menemukan dimensi mana saja dan struktur primer - produk, fungsi atau konsumen - yang merupakan pengerak keputusankeputusan kunci yang paling logis. Apabila pelaku pengambil keputusan melakukan analisis keputusan sesudah mengusulkan sebuah struktur utama, pengambil keputusan akan menonjolkan s'emua titik-titik konflik di mana struktur yang diusulkan dapat menghambat keputusan. Adapun cam yang diambil, desain keputusan akan membantu pengambil keputusan mendefinisikan proses pembuatan keputusan, mengidentifikasi keterampilanyang akan dibutuhkan, dan memastikan keterampilan-keterampilan tersebut tidak absen. ${ }^{26}$

\footnotetext{
${ }^{24}$ Ibid, h. 73

${ }^{25}$ Ibid, h. 74

${ }^{26}$ Ibid
} 


\section{Didin Sirojudin.}

Dengan demikian, penulis menyimpulkan bahwa langkah-langkah dalam pembuatan keputusan dimulai dengan mengidentifikasi masalah hingga mengevaluasi alternatif yang diambil.Selain itu memunculkan tujuan organisasi dapat dijadikan sebagai alat ukur kemajuan organisasi sebelum mengambil alternatif pembuatan keputusan.

\section{F. Jenis-Jenis dan Fungsi Keputusan}

Proses pembuatan keputusan yang dijalankan secara baik akan melahirkan putusanputusan organisasi, baik diputuskan secara pribadi setelah menerima informasi dari bawahan melalui musyawarah maupun putusan diambil sendiri oleh manajer tanpa melibatkan bawahan.

Secara umum keputusan dibagi kepada dua jenis, yaitu: ${ }^{27}$

a) Keputusan strategis

Setiap organisasi melahirkan berbagai kebijakan atau keputusan organisasional.Kebijakan dan arah organisasi merupakan keputusan strategis.Kebijakan menyita banyak perhatian terutama bagi para manajer puncak karena pengaruhnya sangat besar terhadap pertumbuhan dan kelangsungan organisasi.

b) Keputusan operasional

Keputusan operasional menyangkut pengelolaan organisasi sehari-hari.Keputusan operasional sangat menentukan efektifitas keputusan strategis yang diambil oleh para manajer puncak. Dengan demikian, keputusan yang diambil dalam proses manajemen balk manajer puncak maupun manajer menengah dan manajer rendah adalah harus saling sinergi agar memiliki kekuatan untuk menembus faktor-faktor eksternal dalam menuju masa depan organisasi yang lebih baik.

Di nisi lain ada pula pembagian keputusan berdasarkan masalah yang dihadapi, yaitu: ${ }^{28}$

a) Keputusan yang diprogramkan (Programmed decision)

Keputusan ini adalah keputusan yang dibuat berdasarkan problem yang diketahui secara balk atau masalahnya diketahui secara jelas. Informasi juga tersedia secara mencukupi untuk digunakan dalam mengambil keputusan.

\footnotetext{
${ }^{27}$ Syafaruddin, Manajemen Lembaga, h. 57.

${ }^{28}$ Ibid
} 


\section{Relevansi Pembuatan Keputusan Dalam Organisasi Pendidikan Islam}

b) Keputusan yang tidak diprogramkan (Non-programmed decision) Keputusan ini adalah keputusan yang diambil berdasarkan masalah yang tidak diketahui secara jelas atau data dan informasinya kurang tersedia sebagaimana mestinya.

Ada pula pendapat lain yang membagi keputusan kepada dua jenis yaitu: (1) keputusan administratif, yaitu semua keputusan yang berbau administrasi operasional sehari-hari; (2) keputusan strategis, yaitu keputusan yang diambilberkaitan dengan tujuan (goal). Keputusan strategis bersifat jangka panjang dan berfungsi sebagai pegangan dalam keputusan administratif. $^{29}$

Setiap keputusan yang diambil para manajer organisasi tertentu dalam jenis keputusan apapun akan menentukan tindakan manajerial yang dijalankan dalam organisasi. Karena bagaimanapun, keputusan memiliki fungsi tersendiri dalam perspektif manajemen. Setidaknya terdapat dua fungsi pokok keputusan, yaitu: (1) sebagai pangkal tolak semua kegiatan manusia yang sadar dan terarah, baik kegiatan individual maupun komunal dalam organisasi; (2) menentukan masa depan, sebab keputusan bersifat futuristik maka efeknya akan terlihat pada masa akan datang meskipun penuh ketidakpastian maka keputusan harus dibuat dalam totalitas perencanaan. ${ }^{30}$

Dari uraian di atas, penulis menyimpulkan bahwa keputusan dan sistematikanya tidak lepas dan proses yang dijalankan sesuai dengan kebutuhan dan mekanisme yang telah ditentukan sehingga keputusan berproses dalam ruang dan waktu yang kadang memiliki jenjang yang berhubungan dengan tingkat pengambil keputusan (top manager, middle manager, low manager). Atau sesuai dengan kebutuhan penjenjangan dalam organasasi atau lembaga yang ada.

\section{G. Kesimpulan}

\footnotetext{
${ }^{29}$ Ibid, h. 58

${ }^{30}$ Ibid
} 


\section{Didin Sirojudin.}

Membuat Keputusan merupakan salah satu upaya strategis dalam menjalankan organisasi, harus diambil setelah melakukan proses perencanaan, menjatuhkan pilihan pada salah satu alternatif pemecahannya bila dihadapkan dengan berbagai macam pilihan

Keputusan dalam lembaga pendidikan islam merupakan langkah memecahkan msalah yang terdapat disaat merancang sebuah pendidikan untuk mencapai tujuan setelah mengevaluasi hal - hal yang bersangkutan dalam pendidikan, oleh sebab itu pengambilan keputusan haruslah relevan dengan sebuah tujuan dan perencanaan. Sebuah keputusan dapat berarti hasil rumusan pemikiran yang didasarkaan pada visi dan misi sebuah lembaga untuk mengatur jalannya pekerjaan demi mencapai tujuan bersama.

\section{H. Daftar Pustaka}

KBBI offline, 2010- 2013 diambil dari http://pustakabahasa.kemdiknas.go.id/kbbi

Sabri, 2013. Kebijakan dan Pengambilan Keputusan dalam Pendidikan Islam, Jurnal AlTa'lim Jilid 1 Nomor 5.

Syafaruddin, 2005. Manajemen Lembaga Pendidikan Islam, Jakarta: Ciputat Press

Gibson, James L. 2003. Organitations. Behavior, Structure, Process (New York: McGraw Hill.

Hesselbein, Frances. etal. (Eds.), 2001. Organisasi Masa Depan. Terj. Achmad Kemal, cet. 2. Jakarta: Elex Media Komputindo.

Siagian, Sondang P. 1989. Fungsi-Fungsi Manajerial. Jakarta: Bina Aksara.

Ambar Sutjahjanti, "Kualitas dan Nilai Infonnasi sebagai Proses Pembuatan keputusan dan Pengendalian Manajemen," dalam Jurnal E,konomi dan Man4emen,vol. VI.

Ashoumi, Hilyah \& Putri Syarifah. 2018. "Manajemen Internalisasi Nilai Pendidikan Agama Islam di Sekolah Dasar : Strategi Sekolah Melalui 5S ”dalam Jurnal Dirasat : Jurnal Manajemen dan Pendidikan Islam 4 (1), 103-116.

Usman, Husaini. 2006. Manajemen Teori, Praktik, dan Riset Pendidikan. Jakarta: Bumi Aksara. 


\section{Relevansi Pembuatan Keputusan \\ Dalam Organisasi Pendidikan Islam}

Qomar, Mujamil. 2007. Manajemen Pendidikan Islam, Jakarta: Erlangga. 


\section{Didin Sirojudin.}

